\title{
Acil Serviste Herediter Anjioödem’e Güncel Yaklaşım
}

\section{Current Approach to Hereditary Angioedema at Emergency Department}

\section{Öner Özdemir}

Sakarya Üniversitesi Eğitim ve Araştırma Hastanesi, Çocuk İmmünolojisi ve Alerji Hastalıkları Bölümü, Adapazarı, Sakarya

\author{
Yazışma Adresi / Correspondence:
}

\section{Öner Özdemir}

Sakarya Üniversitesi Tip Fakültesi, Sakarya Üniversitesi Eğitim ve Araștırma Hastanesi, Çocuk İmmünolojisi ve Alerji Hastalıkları Bölümü,

T: +90264 $4445400 \quad$ E-mail: ozdemir_oner@hotmail.com

Geliş Tarihi / Received : 01.10.2019 Kabul Tarihi / Accepted : 09.02.2020

Orcid:

Öner Özdemir https://orcid.org/0000-0002-5338-9561

( Sakarya Tip Dergisi / Sakarya Med J 2020, 10(1):152-161) DOI: 10.31832/smj.627591

Öz

Herediter anjioödem (HAÖ) nadir görülen, genelde C1 inhibitör (C1-INH) eksikliğine bağll, tekrarlayan anjioödem ataklarılyla bilinen ve ölümcül olabilen otozomal dominant geçişli bir hastalıktır. Anjioödem atakları genellikle aniden oluşur, sıklıkla tahmin edilemez ve tipik olarak ekstremite, gövde, yüz, karın, genital organlar ve üst solunum yollarını tutan șisliklere yol açar. Hastaların yaklașık 1/3’ünde prodromal dönemde eritema marginatum benzeri döküntü görülebilir. Herediter anjioödem hastalarında tipik olarak eşlik eden ürtiker olmaması sıklıkla nonhistaminerjik (bradikinerjik) anjioödem şeklinde düşünülmesine yol açar. Ataklar önemli derecede işlevsel bozukluğa, yaşam kalitesinin azalmasına ve larengeal atak olgularında ise ölüme yol açabilir. Herediter anjioödemin karın tutulumuyla giden atağı genelde tanıda gecikme ve uygunsuz tedaviye neden olan ailevi Akdeniz ateși (AAA) ve apandisit gibi bazı akut batın durumlarını taklit eder. Herediter anjioödem tedavisi kısa ve uzun süreli profilaksi ile atak tedavilerini içerir. Günümüzde kullanılan dört tür akut/atak tedavi seçeneği arasında, plazma kaynaklı C1-INH konsantresi, rekombinant C1-INH konsantresi, ecallantide ve ikatibant sayılabilir.

Anahtar Herediter anjioödem; atak; acil servis; $\mathrm{C} 1$ inhibitör; ikatibant

Hereditary angioedema (HAE) is an uncommon, mostly due to CI inhibitor (C1-INH) deficiency, possibly fatal disorder known by episodic angioedema attacks with autosomal dominant inheritance. Angioedema attacks are generally sudden, often unpredictable and causing swelling typically affecting the extremities, trunk, face, abdomen, genitalia, and upper airways. Erythme marginatum-like rash is seen in $1 / 3$ of the patients during prodromal period. Since HAE patients characteristically have no concomitant urticaria, they are frequently considered as nonhistaminergic (bradykinergic) angioedema. Attacks may lead to significant functional impairment, decreased quality of life, and fatality due to laryngeal attacks. Abdominal attack of HAE usually resembles several acute abdominal situations, such as familial mediterranean fever (FMF) and appendicitis causing a deferral of exact diagnosis and unfitting therapies. Treatment for HAE involves long- and short-term prophylaxis as well as management of attacks. Among four attack treatment options, plasma-derived C1-INH concentrate, recombinant C1-INH concentrate, ecallantide, and icatibant are utilized nowadays.

Keywords Hereditary angioedema; attack; emergency; Cl inhibitor; icatibant 


\section{GíRiş}

Genellikle C1 esteraz inhibitör (C1-INH) eksikliğine bağlı oluşan herediter anjioödem (HAÖ) cilt, barsak submukozası ve üst solunum yollarını tutan; kaşıntı ve ürtiker olmadan tekrarlayan anjioödem ataklarıyla giden otozomal dominant geçiş gösteren bir hastalıktır. ${ }^{1}$ Nadir görülmesine rağmen acil serviste atak tedavisinde yaşanan gecikme ve sıkıntılardan dolayı; bu derlemede öncelikle HAÖ hastasına acil serviste çalışan bir hekimin tanısal ve sonrasında tedavi açısından nasıl yaklaşması gerektiği anlatılmaya çalışlacaktır. Ayrıca Dünya’da ve ülkemizde güncel uygulanan tanı ve tedavi yöntemlerine değinilecektir.

\section{Herediter Anjioödemli Hastaların Acile Başvuru Sıklığı}

Amerika Birleşik Devletleri’nde yapılan bir araştırmada ömür boyu görülen anjioödem ve/veya ürtiker prevalans1 toplumda $\% 25$ oranında saptanmış ve yılda 1.000 .000 üstünde acil vizitine yol açtığı hesaplanmıştır. Bunların yaklaşık 110.000/yl anjioödem (herediter veya akkiz); 979.400'ü de alerjik reaksiyon şeklinde kodlanmıştır. ${ }^{2}$ Amerika Birleşik Devletleri’nde her 100.000 acil vizitinin 2'si, İtalya'da ise 10.000'nin 37'sinin sadece HAÖ kaynaklı olduğu bildirilmektedir. ${ }^{3-5}$ Acil vizitlerinin herhangi bir nedene bağlı anjioödemilişkili olma oranı İtalyàda: 4/1.000, Kanada'da ise 1/1.000 olarak saptanmıştır.

\section{Herediter Anjioödemin Prevalansı}

Nadir görülen bir hastalık olmasına ve Türkiyede nüfusa göre 500- 7.500 hasta olduğu tahmin edilmesine rağmen, tiplerine göre HAÖ sıklığının 1/50.000- 400.000 arasında değiştiği düşünülmektedir. ${ }^{6,7}$

\section{Herediter Anjioödemin Acilde Karşılaşabileceğimiz Klinik Tipleri}

Herediter anjioödem esas olarak C1-INH yapısal / işlevsel eksikliği olup olmadığına göre, son zamanda iki büyük gruba ayrılmaktadır. C1-INH'ün yapısal / işlevsel eksikliğine bağlı tip C1-INH-HAÖ ve önceden Tip III de denilen normal C1-INH serum düzey ve işlevleriyle giden tip
nC1-INH-HAÖ şeklinde sınıflanmaktadır. ${ }^{8}$

C1-INH'ün yapısal (antijenik / proteinsel) eksikliğine bağlı C1-INH-HAÖ tipi, tip I ve tip II olarak ayrilmaktadır. Tip I daha sık rastlanmakta olup (<\%80-85) serum antijenin düşüklüğüne bağlıdır. Tip II daha nadir olup $(<\% 15)$ C1-INH işlevsel eksikliğine bağlıdır.,10

Klinik olarak benzemekle beraber, nC1-INH-HAÖ’nün patofizyolojisinde son zamanlarda koagülasyon Faktör 12 (sadece \%25'inde), Plazminojen (PLG) ve Anjiopoetin-1 (ANGPT-1) gen mutasyonları saptanmıştır. Kadın hastalarda daha sık görülmesi ve östrojen, anjiotensin konverting enzim inhibitörü (ACE-I) gibi ilaçlarla sık alevlenme göstermesi bu tipin karakteristiklerindendir. ${ }^{11-13}$

\section{Herediter Anjioödemin Tanısı Nasıl Konulur?}

HAÖ hastalığ ya C1-INH gen ya da koagülasyon aktivasyon sistemini ilgilendiren Faktör 12, PLG veya damar endotel yapısıyla ilişkili ANGPT-1 gen mutasyonları sonucu artmış mediatör bradikinin birikimine veya endotelden sızmaya bağlı oluşan şişliklerle kendisini gösterir., ${ }^{1,8-13}$

Tanıdaki en büyük sorun HAÖ’nün akla gelmemesidir. Diğger hastalıklarda olduğu gibi, öykü, fizik muayenedeki klinik bulgular, laboratuvar testleri (C4, C1-INH antijenik düzeyi, C1-INH fonksiyonel düzeyi vb.) ve genetik testler (SERPING1, Faktör 12, PLG, ANGPT-1 mutasyon analizi) ile tanı kesinleştirilir. ${ }^{14-17}$

\section{Acile Gelen Hangi Hastalarda Düşünülmelidir?}

Tekrarlayan ve nedeni açıklanamayan, 24 saati geçen, anti-histaminiklere cevap vermeyen, ürtikerin eşlik etmediği, bazen larenks ödemi veya barsak ödemi sonucu kolik tarzında karın ağrısı geliştirebilen ve aile öyküsü olan anjioödem vakalarında HAÖ tanısının düşünülmesi gereklidir. $^{1,5,18}$

\section{C1-INH-HAÖ (Tip I ve II) Tanısı İçin Kriterler}

Literatürde rehberlerde belirtilen üç majör klinik, 1 minör 
klinik ve 3 laboratuvar bulgusu tanımlanmıştır. Rehberlere göre, 1 major klinik bulgu ve 1 laboratuvar bulgu ile tanı konulabilir. ${ }^{1,17}$ Tanıda aile öyküsü şart değildir ve olguların yaklaşık \%25'inde aile öyküsü bulunmaz (spontan mutasyonla hastalık oluşur).

Major klinik bulguların içinde; i-) ürtikerin eşlik etmediği, 12 saati aşan, nonenflamatuar anjioödem, ii-) tekrarlayan larenks ödemi iii-) kendinden gerileyen ve organik nedene bağlı olmayan karın ağrısı atakları ve tek minor klinik bulgu olarak ailede tekrarlayan larenks ödemi, karın ağrısı veya anjioödem öyküsünün olması denilmektedir. Laboratuvar bulgusu olarak da genetik mutasyonun (C1-INH) saptanması ya da 1 yaş üstü bir çocukta C1-INH antijen düzey/işlevinde \%30'dan fazla azalma kriter olarak konulmuştur.

\section{nC1-INH-HAÖ tanısı için kriterler}

Yukarıdaki kriterler C1-INH-HAÖ (Tip I ve II) tanısı için konulmakla beraber, nC1-INH-HAÖ tanısı için laboratuvar kriterlerinde farklılıktan bahsedilebilir. Ürtikerolmadan nedensiz tekrarlayan anjioödemde, C1-INH düzey/ işlevi (kompleman C4 düzeyi ile beraber) normalse; genetik olarak F12, PLG, ANGPT-1 mutasyonunun saptanması veya aile öyküsü ile beraber anti-histaminiğe cevapsızlığın gösterilmesi gerekmektedir. ${ }^{17,19}$

\section{Herediter Anjioödem'in Acilde}

\section{Daha Sıklıkla Karşılaşılan Klinik Bulguları}

Sıklığ 608 yüz atağında veya 2134 toplam atakta 1 olan ve atak başladıktan 1-7 saat sonra gelişebilen hava yollarında (larenks/gırtlak) şişlik ölümcül olup acil müdahale gerektirir. Yine anjioödem olmadan da gelişebilen şiddetli kolik tarzı karın ağrısı ile de hasta gelebilir ve bu hastalara çoğu zaman eksploratris (tanısal) laparoskopi ve appendektomi yapılmak zorunda kalınmaktadır. ${ }^{1,5}$ Hastalıkta görülen karın ağrısı atakları FMF ile de karıştırılabilir, fakat çok nadiren de olsa HAÖ’nün FMF ile beraber görüldüğü literatürde bildirilmiştir. ${ }^{18}$

\section{Herediter Anjiyoödemin Tanısında Laboratuvar Yöntemleri}

C1-INH-HAÖ (Tip I) tanısı için laboratuar yöntemleri olan $\mathrm{C} 4$ ve C1-INH antijen düzey saptanması günümüzde Türkiye'de çoğu hastanede mümkün olmakla beraber, sonuçların elde edilmesi geciktiğinden, yine C1-INH işlevi ve mutasyonlar çoğu yerde çalışılamadığından acil şartlarında HAÖ tanısı koymak zordur. Ama asıl problem, nadir görüldügünden acil şartlarda hekimin HAÖ hastalığını düşünememesi ve öncelememesidir. ${ }^{1,20}$

\section{Bradikininerjik Anjioödemin}

\section{Histaminerjik Olandan Ayrılması}

Histamin -aracılı (histaminerjik, alerjik) ve ACE-i gibi ilaçlara bağlı Bradikinin-aracılı (bradikininerjik) meydana gelen anjioödem tiplerinin daha sık, ancak HAÖ’nün daha nadir görüldüğünün bilinmesi gerekmektedir. HAÖ, özellikle ürtikersiz (kabarıksız) anjioödemin -angioedema without wheals: AEWoW- ayırıcı tanısına girer. AEWoW denilen bu tip, histamin-aracılı (IgE/direkt/kompleman üzerinden Mast hücrenin uyarılmasına bağlı veya nonsteroit anti-inflamatuvar ilaç: NSAID alerjisi) ya da bradikinin-aracılı (ACE-inhibitörü, kazanılmış anjioödem, HAÖ) olabilmektedir. ${ }^{1,21-23}$

Histaminerjik anjioödem daha kısa süreli olması ve antihistaminik tedaviye cevap vermesi dişında, alerjenle tetiklendiğinden ürtiker-anjioödemden başlayıp tip I / IgE-aracılı reaksiyonu hatırlatan tipte anafilaksiye kadar ilerleyebilir. Bradikininerjik anjioödem travmayla tetiklenmesi, daha uzun / şiddetli olması, antihistaminiklere cevap vermemesi ve larenks ödemi daha sık görülmesine rağmen anafilaksiye dönmemesi ile tanınır. ${ }^{24-26}$

\section{Ayırıcı Teşhis}

Herediter anjioödem dışında altta yatan başka hastalıklar da bradikininerjik anjioödeme yol açabilir. HAÖ’nün histaminerjik anjioödem yapan nedenler dışında bu tip anjioödeme neden olan hastalıklardan da ayrilması zorunludur. Örneğin akkiz C1-INH eksikliği malign (len- 
foprolifratif hastalık) veya Lupus gibi otoimmun hastalıkta artmış C1-INH proteininin katabolizmasına bağlı oluşabilir. Yine erişkinlerde ACE-i dışında diğer bazı ilaçların (Renin inhibitörü, DPP-4 inhibitörleri, r- tPA, sirolimus, everolimus, vb.) da anjioödeme yol açabileceği bilinmelidir. Yine bazı sendromların Muckle-Wells sendromu (amiloid birikimi), Melkersson-Rosenthal sendromu (granülömatöz), Laffer Ascher's sendromu, Gleich's sendromu, vb. anjioödem benzeri şişliklerle seyredebildiği bilinmelidir. Yine, sistemik kapiller sızıntı sendromu (Clarkson sendromu); vücutta nodül, eozinofili, romatizma, dermatit ve şişme oluşumu ile karakterize NERDS sendromu, eozinofilik fasiit ve deri amiloidozu ayırıcı tanıda akılda tutulmalıdır 1,21,24,26,27 Anjioödem ayırıcı tanısını anlatan detaylı tabloya bakilabilinir (tablo 1).
Derlemenin bu ikinci kısmında da günümüzde diğer ülkelerde ve ülkemizde uygulanan yeni kullanılan tedavi yöntemlerinden bahsedeceğiz.

\section{Günümüzde Acil (Atak, Gereği) \\ Durumda Kullanılan İlaçlar}

Tedavide yaklaşım olarak, yapılabilirse tetikleyici faktörlerden sakınılarak atakları önleme ya da azaltma ilk planda düşünülebilir. Her zaman tetikleyicilerden sakınma mümkün olamayacağından, burada özellikle akut (atak/acil) tedavi üzerinde durulacaktır. ${ }^{28,29}$ Günümüzde acil/atak tedavisi terimi yerine, hastanın tedaviyi yönlendirebilmesi (kontrolüne sahip olması) ve tedaviye erişimin engellenmemesi için ihtiyaç halinde / gereğinde -'on demand' tedavi deyiminin kullanımı daha çok tercih edilmektedir.

Tablo 1. Herediter ve akkiz anjioödem tiplerinin klinik özellikleri

\begin{tabular}{|c|c|c|c|c|c|c|c|}
\hline \multirow[b]{2}{*}{ Klinik Özellikleri } & \multicolumn{3}{|c|}{ Herediter AÖ (HAÖ) } & \multicolumn{4}{|c|}{ Akkiz AÖ (AAÖ) } \\
\hline & $\mathrm{C} 1-\mathrm{INH}$ & FXII & $\begin{array}{c}\text { Bilinmeyen/ } \\
\text { Diğerleri }\end{array}$ & Histm. AÖ & $\begin{array}{c}\text { Non Histm. } \\
\text { AÖ }\end{array}$ & $\begin{array}{l}\text { C1-INH } \\
\text { AAÖ }\end{array}$ & ACE-i AÖ \\
\hline Ekstremitede Anjioödem & +++ & +++ & +++ & + & + & ++ & $+/-$ \\
\hline Dilde Anjioödem & + & + & + & ++ & ++ & ++ & +++ \\
\hline Girtlakta Anjioödem & +++ & +++ & +++ & + & + & +++ & +++ \\
\hline $\begin{array}{l}\text { Gastrointestinal An- } \\
\text { jioödem }\end{array}$ & +++ & +++ & +++ & $+/-$ & $+1-$ & ++ & $+/-$ \\
\hline Östrojenin etkisi & ++ & +++ & + & - & - & - & - \\
\hline Başlangıç Süresi (< 6 saat) & + & + & + & +++ & ++ & + & ++ \\
\hline Atak Uzunluğu (> 48 saat) & +++ & +++ & +++ & + & + & +++ & ++ \\
\hline Aile öyküsü & +++ & + & +++ & - & - & - & - \\
\hline Görülme yaşı & $3-20$ & $>20$ & $>20$ & $>30$ & $>30$ & $>50$ & $>30$ \\
\hline Cinsiyet & $\mathrm{E} \approx \mathrm{K}$ & $\mathrm{K}$ & $\mathrm{K}$ & $\mathrm{E} \approx \mathrm{K}$ & $\mathrm{E} \approx \mathrm{K}$ & $\mathrm{E} \approx \mathrm{K}$ & $\mathrm{E} \approx \mathrm{K}$ \\
\hline Ürtiker birlikteliği & - & - & - & + & - & - & - \\
\hline $\begin{array}{l}\text { Prodromal eritema mar- } \\
\text { ginatum }\end{array}$ & + & - & - & - & - & - & - \\
\hline Serum C4 & $\downarrow$ & $\mathrm{N}$ & $\mathrm{N}$ & $\mathrm{N}$ & $\mathrm{N}$ & $\downarrow$ & $\mathrm{N}$ \\
\hline Serum C1q & $\mathrm{N}$ & $\mathrm{N}$ & $\mathrm{N}$ & $\mathrm{N}$ & $\mathrm{N}$ & $\downarrow$ & $\mathrm{N}$ \\
\hline $\mathrm{C} 1 \mathrm{INH}$ antijen düzeyi & $\downarrow$ & $\mathrm{N}$ & $\mathrm{N}$ & $\mathrm{N}$ & $\mathrm{N}$ & $\mathrm{N}, \downarrow$ & $\mathrm{N}$ \\
\hline C1 INH fonksiyonu & $\downarrow$ & $\mathrm{N}$ & $\mathrm{N}$ & $\mathrm{N}$ & $\mathrm{N}$ & $\downarrow$ & $\mathrm{N}$ \\
\hline Antihistaminiğe yanıt & - & - & - & + & - & - & - \\
\hline \multicolumn{8}{|c|}{$\begin{array}{l}\text { Kısaltmalar: AÖ: anjioödem; C1-INH: C1 esteraz inhibitör; FXII: koagülasyon faktör 12; ACE-i: anjiyotensin konverting enzim inhibitör; C1-INH HAÖ: C1- } \\
\text { INH eksikliğine bağlı herediter anjioödem; FXII-HAÖ: faktör } 12 \text { gen mutasyonuna bağl1 herediter anjioödem; Histm. AÖ: rekürren idiopatik ailevi olmayan } \\
\text { antihistaminiğe duyarlı anjioödem; Non-Histm. AÖ: rekürren idiopatik ailevi olmayan antihistaminiğe duyarsız/cevapsız anjioödem; C1-INH AAÖ: rekürren } \\
\text { ailevi olmayan sekonder /tüketim sonucu C1-INH eksikliğine bağlı akkiz anjioödem; ACE-i AÖ: rekürren ailevi olmayan anjiyotensin konverting enzim } \\
\text { inhibitör kullanımına bağlı akkiz anjioödem, N: normal, 囚: düşük, K: kadın, E: erkek; ₹: yaklaşık eşit. }\end{array}$} \\
\hline
\end{tabular}


Profilaktik tedaviye rağmen hastalık kontrolünün sağlanamadığı ya da herhangi bir tetikleyici ile beklenmeyen durum ve zamanda aniden gerçekleşen HAÖ ataklarında acil ya da ihtiyaca bağlı tedavi zorunlu olabilir. Acil hekimi açısından en önemli nokta, acile başvuran hastada HAÖ atağının diğer karıştırılabilen histaminerjik ve bradikininerjik anjioödeme bağlı atak türlerinden ayrımının öncelikle yapılmasıdır. ${ }^{1}$ Ayrıca bu ataklarda anti-histaminik, adrenalin ve kortikosteroit gibi ilaçların etkisiz kaldığı acilde çalışan hekimlerce bilinmelidir. ${ }^{30-32}$

Aşağıda öncelikle, acil tedavide günümüzde literatürde bildirilen tüm ilaçlardan bahsedildikten sonra, ülkemizde kullanılan ilaçlar daha detaylı anlatılacaktır.

\section{Literatürde Bildirilen ve Atak Tedavisi İçin Geliştirilmiş Tüm İlaçlar}

Tedavideki amaç, vücutta plazma kontakt (kallikrein-kinin) sisteminin son ürünü olan ve HAÖ atağına neden olan kininlerin birikimini ya da etkisini engelleyerek atağın kontrolünün sağlanmasıdır. Bu, vücutta eksik C1-INH proteininin yerine konulması ve/veya plazma koagülasyon sisteminin (F12/PLG üzerinden) bradikinin üretiminin ya da aşırı çalışmasının önlenmesi yoluyla başarılmaya çalış1lır. ${ }^{28-32}$

Acil tedavide bugüne kadar geliştirilen tüm ilaçları aşağıda 6 grup halinde sinıflayabiliriz. ${ }^{6,18,20,33-38}$

I. Antifibrinolitikler: Epsilon $(\varepsilon)$-amino kaproik asit ve traneksamik asit

II. Zayıf (anabolik) androjenler: Danazol, stanozolol, metiltestosteron, oksandrolon

III. Plazma kaynaklı ya da rekombinant C1-INH antijeni içeren ürünler: Plazma konsantresi (Cinryze ${ }^{\circledast} / \mathrm{Be}-$ rinert $^{\circledast}$ ) ve rekombinan antijen (Rhucin ${ }^{\circledast} /$ Ruconest $\left.^{\circledast}\right)^{39-41}$ IV. Plazma kallikrein inhibitörleri: subkutan uygulanan Ecallantide (DX88, Kalbitor ${ }^{\bowtie}$,

V. Bradikinin reseptör inhibitörü: Icatibant içeren ürünler $\left(\right.$ Firazyr $^{\circledast}$, İcatin $^{\circledast}$, Bradikant $\left.^{\circledast}\right)$

\section{Solvent deterjan / Taze donmuş plazma ${ }^{34-37,42-45}$}

Birinci ve ikinci gruptaki ilaçlar ilk zamanlar hem atak hem de profilaktik tedavi için kullanılsalar bile, atak sırasındaki etkinlikleri gecikmeli ve zayıf olduğundan kullanımları tartışmalıdır. Günümüzde 3.-5. arası gruptan ilaçlar tercih olunmalıdır. Çaresiz kalındığında yine birinci ve ikinci gruptan ilaçlar kullanılabilir. Altıncı grup ise, acilde hiçbiri yoksa son çare olarak kullanılabilecek ilaçtır. Solvent deterjan plazma, ülkemizde yaygın kullanılmamaktadır.

Ülkemizde kısmen yeni ilaçlar olan rekombinan C1-INH antijeni (Rhucin ${ }^{\circledast}$ Ruconest $^{\circledast}$ ) ve Ecallantide $\left(\right.$ Kalbitor $\left.^{\circledast}\right)$ içeren ürünler bulunmamaktadir.

\section{Ülkemizde Acil'de Uygulanan Tedavi Yöntemleri}

Günümüzde ülkemizde aktif olarak acil tedavi için halen kullanılan tüm ilaçları aşağıdaki gibi grup halinde daha detaylı şekilde anlatabiliriz.

\section{1-) Antifibrinolitik ilaçlar}

Daha önceki yıllarda epsilon ( $(\varepsilon)$ amino kaproik asit (EACA) kullanılsa dahi, sonraki yıllarda yerini Traneksamik asit'e bırakmıştır. EACA’nın erişkin dozu günde 2 kere $2 \mathrm{gr}$ (1$4 g r)^{\prime}$ dır. Çocuklarda günde 2 kere $0.025-0.1$ gr $/ \mathrm{kg}$ 'ır. Traneksamik asit'in erişkin dozu günde 2 kere 1 gr (0.25-1.5 gr) 'dır. Çocuklarda doz günde 2 kere 10 - 25 mg/kg'dır. Bunlar, plazminojen aktivasyonunu inhibe ederek etkili olur. Androjenlere göre daha zayıf etkilidirler. Postural hipotansiyon, kas krampları, ishal, retinal tümör gelişimi ve karaciğer işlev bozukluğuna yol açma gibi yan etkileri olabilir. İlaç kullanımına başlanılmadan trombo-embolizm / trombofili açısından zorunlu incelemeler yapılarak tedavi başlanılmalı ve kullanırken de buna dikkat edilmelidir. ${ }^{28,29}$ İlk zamanlar atak ve profilaksi tedavisinde kullanılsa bile, günümüzde çok tercih edilmemektedir. Androjenlerle karşılaştırıldığında daha az etkin olmakla birlikte, traneksamik asit, diğer ilaçların elde edilmesi mümkün olmadığ 
durumlarda atakta denenebilir. ${ }^{18,46-50}$

\section{2-) Zayıf /anabolik androjenler}

Tüm Dünya'da en iyi bilinen ve en sık kullanılan ürün Danazol'dür. Ülkemizde de Danazol'un HAÖ tedavisinde SGK tarafindan geri ödemesi bulunmaktadır. Stanozolol Amerikan Gıda ve İlaç Dairesi (FDA) tarafından çocuklarda kullanımı onaylanmış olmasına rağmen, ülkemizde bulunmamaktadır. Metiltestosteron çaresiz kalındığında erkeklerde denenebilir.

Androjenler, karaciğgerden C1-INH protein sentezini art1rarak etkisini göstermektedirler. Bazı rehberlerde özellikle yan etki riskinden dolayı, hastalardan yazılı onam alınıp başlanılsın denilmektedir. Yine puberte evrelemesi Tanner 5 'in üstünde olan hastalarda kullanılabileceği söylenilmektedir. Tedavinin yan etkileri olarak, kilo alma, virilizasyon, menstruel bozukluk, karaciğer enzim yüksekliği ve hepatoselüler adenomaya yol açabildiği bildirilmiştir.

Danazol tedavisine başlamak için (Milan ve Budapeşte) protokolleri önerilmiştir. Milan protokolünde kısmen yüksek doz (400 mg/gün) ile başlanıp, gerekirse 600 mg’a kadar çıkılıp, aylık aralarla doz $50 \mathrm{mg} /$ gün, 5 gün/hafta dozuna inilmeye çalışılır. Budapeşte protokolünde kısmen düşük doz (200 mg/gün) ile başlanır, gerekirse doz 400 mg'a artırılır ve daha sonra 2-4 hafta ara ile $50 \mathrm{mg} /$ gün haftada 7 gün dozuna indirilmeye çalış1lır., 6,18,20,34-37

Anabolik androjenler ağıdan kullanım kolaylığı olan ve daha ucuz ilaçlar gibi görünse de, kas krampları, psikiyatrik problemler, obezite, hiperlipidemi gibi komplikasyonlara yol açmaları nedeniyle bu tedavinin dolaylı maliyeti yükselebilmektedir. ${ }^{38}$

Androjenler gibi antifibrinolitik ilaçlar eskiden kullanılmış olmakla beraber yeni çıkan ilaçlara göre daha etkisiz görüldüğünden günümüzde terk edilmişlerdir. Danazol tedavisinin etkisi ortalama 1 ile 2 gün içinde başlamaktadır. Bu nedenle atak tedavisinde iyi bir seçenek olmadığı düşünülse de, genel yaklaşım olarak uzun dönem profilaksi tedavisi alan hastalarda kullandıkları doza rağmen atak geçirme durumunda danazol tedavisinin dozunu 2 katına çıkılması önerilmektedir. ${ }^{18,46-50}$

\section{3-) Plazma Kaynaklı C1-INH İçeren Ürüinler}

Atakta, kısa-uzun süreli profilakside ve gebelik sırasında uygulanabilir. Plazma konsantresi olarak ülkemizde Cinryze $^{\oplus}$, diğer ülkelerde Berinert ${ }^{\circledast}$ bulunmaktadır. Diğer ülkelerde bunlara ilaveten atak tedavisinde yine intravenöz verilen rekombinan C1-INH antijeni (Rhucin/ Ruconest ${ }^{\oplus}$ ) de kullanılmaktadır.

Cinryze ${ }^{ø}$ preparatı Amerikan FDA tarafından kullanımı onaylanmış çözücüsüyle beraber 500 ünite $/ 5 \mathrm{ml}$ liyofilize flakon halinde damar içi uygulanan bir ticari ürün olup, mümkünse $+2-+8{ }^{\circ} \mathrm{C}$ arasında, mutlaka $25^{\circ} \mathrm{C}$ altında saklanmalıdır. Çalkalama yapılmadan eritilip hazırlanmalıdır. Vücut ağırlığı 25 kg'dan düşük ise 500 ünite, 25 kg’’n üzerinde ise 1.000 ünite verilir. Uygulamaya hazır solüsyon oda isısında en fazla 8 saat süreyle bekletilebilir. Periferik venlerden damar içine verilir. İnfüzyonun yavaşça verilmesi ( $1 \mathrm{ml} /$ dakika) gerekmektedir. İnfüzyon toplam süresi 5 dakikadan daha az olmamalıdır. Kandan elde edilen bir ürün olduğundan kanla bulaşan bazı viral hastalıkları bulaştırma riskini diğer kan ürünlerindeki gibi taşımaktadir. ${ }^{19,20}$

C1- inhibitör yerine koyma tedavisinde uygulanan ticari ürünler 2 yaş ve üstünde kullanılabilir. Ataklarda C1-INH yerine koyma tedavisi çocukta 10-20 ünite/kg, genellikle 500-2.000 ünite olarak uygulanır. C1- inhibitör damar içi verilmesi durumunda 30-60 dakikada semptomlar hafifler ve 24-48 saat içinde tamamı kaybolur. Kan dolaşımındaki yarılanma ömrü, HAÖ atağının şiddetine bağlı olarak 31- 46 saat arasında değişmektedir. İlacın yan etkileri nadir görülmekle beraber anafilaksiyi düşündüren türde reaksiyon (hızlı ve oda 1sısına getirmeden infüzyona bağlı), ürüne karşı inhibitör türünde antikor geliştirme, bölgesel kızarıklık, ateş, baş ağrısı, yorgunluk gibi semptomları içe- 
rir. $5^{1,52}$

\section{4-) Bradikinin B2 Reseptör Antagonisti / İnhibitörü}

Ülkemizde özellikle ataklarda damar içi C1-INH yerine koyma tedavisinin alternatifi olarak görülür. Türkiye’de 2019 yılı başında Sağlık Uygulama Tebliği (SUT) ile geri ödemeye alındı. Deri altı yolla uygulanan Icatibant dış ülkelerde Firazyr ${ }^{\curvearrowleft}$, yurdumuzda İcatin ${ }^{\circledR}$ ya da Bradikant ${ }^{\circledR}$ müstahzar adıyla satılmaktadır. Dolaşımdaki kısa olan yarılanma ömrü ( $1.4 \pm 0.4$ saat) nedeniyle profilaktik tedavide kullanılmaz. Atak tedavisi sonrasinda 'rebound' etkisi (tedavi edilmeye çalışılan semptomların birden nüks etmesi) görülebileceğinden dikkatli olunmalıdır. İlacın kullanımı kolay, uygulamaya hazır enjektör içinde olup oda ısısında saklanabilmektedir. Kandan elde edilen bir ürün olmadığından daha güvenilirdir. Ülkemizdeki fiyatı kısmen yurt dışına göre daha ucuzdur. Hasta ilacı kendine direkt olarak uygulayabildiğinden tedaviye ulaşmada gecikme sorununu çözebilir. En belirgin yan etki olarak, enjeksiyon bölgesinde acı ve yanmaya neden olabilir. Hamile bayanlarda ilacın kullanımı önerilmez (kategori C). ${ }^{53-57}$

Icatibant $30 \mathrm{mg} / 3 \mathrm{ml}$ çözelti içeren kullanıma hazır enjektörle piyasada bulunur. Icatibant yetişkin, ergen ve çocuk hastalarda ( $\geq 2$ yaş, $\geq 12 \mathrm{~kg}$ ) HAÖ belirtilerinin tedavisinde uygulanabilir. 24 saatte üst üste 3 enjeksiyondan fazla verilmemelidir. Eğer bir ayda 8 enjeksiyondan fazlası gerekiyorsa hasta uzmana danışmalıdır. Çocuklar için kullanılan dozlar hastanın kilosuna göredir: 12-25 kg: $10 \mathrm{mg}(1 \mathrm{ml})$, 26-40 kg: $15 \mathrm{mg}$ (1.5 ml), 41-50 kg: 20 mg (2 ml), 51-65 kg: $25 \mathrm{mg}(2.5 \mathrm{ml}),>65 \mathrm{~kg}: 30 \mathrm{mg}(3 \mathrm{ml})$ olarak kullanımı üretici firma tarafından önerilmektedir. Yetişkinlerde önerilen pozoloji ise, cilt altı $30 \mathrm{mg}$, gerekirse 6 saat sonra ikinci enjeksiyon, 24 saat içerisinde toplamda en fazla 3 enjeksiyon uygulanması șeklindedir.

\section{5-) Taze donmuş plazma (TDP)}

Herediter anjioödem atak tedavisinde TDP uygulaması için önerilen doz 10-20 ml/kg, ortalama 1-2 ünite kullanımıdır. Genelde ortalama 45 dakikada etkili olur. Fakat bazı hastalarda TDP içinde bulunan kinin substratlarından (prekallikrein, F12 ya da kininojen artığı) dolayı HAÖ atağının daha da kötüleşebileceği ihtimali akılda tutulmalidir. ${ }^{6,18,20,33-37,42}$

\section{Acil / Atak (Akut, Gereğinde) Tedavisi Ne Zaman ve Hangi Tutulumda Uygulanmalıdır?}

Bu kararın verilmesi hasta ve hekim açısından çok önemlidir. Uluslararası rehberlere göre, yüz ve boyun tutulumu hariç gövde ve ekstremitelerde oluşan cilt şişliklerinde bekle-gör taktiği uygulanabilir. Girtlağı ve karnı tutan ataklarda beklenmez ve hızlıca atak tedavisi başlanır (tablo 2). Günümüzde ise, her atağın tedavi edilmesi gerektiği görüşü de ön plana çıkmaya başlamıştır. ${ }^{6,18}$

\begin{tabular}{|c|c|c|c|c|}
\hline Ciltte şişlik & \multicolumn{3}{|c|}{ Diğer organ tutulumları } & \multirow[b]{2}{*}{ Strateji } \\
\hline $\begin{array}{l}\text { Gövde, } \\
\text { Ekstremite }\end{array}$ & $\begin{array}{l}\text { Yüz, } \\
\text { boyun }\end{array}$ & $\begin{array}{c}\text { Karın } \\
\text { tutulumu }\end{array}$ & Larenks & \\
\hline+ & \pm & - & - & $\begin{array}{c}\text { Bekle-gör } \\
\text { (spontan düzelme) }\end{array}$ \\
\hline+ & + & + & + & Traneksamik asit \\
\hline - & \pm & + & + & $\begin{array}{l}\text { C1-INH ya da } \\
\text { alternatifleri* }\end{array}$ \\
\hline - & - & - & + & $\begin{array}{l}\text { YBU (entubasyon, } \\
\text { trakeostomi) }\end{array}$ \\
\hline
\end{tabular}

Kısaltmalar: +: ilaç verilsin, \pm : ilaç verilebilir/verilmeyebilir, C1-INH: C1 esteraz inhibitör *: Cl esteraz inhibitör, icatibant, ecallantide, rekombinant C1-INH veya hiçbiri yoksa TDP, YBU: yoğun bakım ünitesi

Yine her acil müdahalede olduğu gibi, HAÖ ataklarında da hastanın hava yolu açıklığının sağlanması ön planda gelmektedir. Günümüzde tüm Dünya'da özellikle dört çeşit ilaç C1-INH plazma konsantresi, rekombinant C1-INH, Icatibant ve Ecallantide atak tedavisinde uygulanmaktadır. Bunların ikisi ülkemizde de mevcuttur. Gerektiğinde ataklarda siv1-elektrolit yerine koyma ve analjezikler ile destekleyici tedavi uygulanabilir. Tercih edilecek bahsedilen 4 ilaçtan biri yoksa, solvent-deterjan plazma varsa kullanılabilir, yoksa yerine taze donmuş plazma da verilebilir. ${ }^{6,20,33,35-37}$ Atak tedavisinde kullanilabilecek tedavi yöntemleri tablo 3'de gösterilmektedir. 


\section{Tedavinin Dikkat Edilmesi Gereken Yan Etkileri}

Özellikle damar içi yoluyla verilen plazma kaynaklı C1INH ürünlerinin (Berinert ${ }^{\circledast}$, Cinryze ${ }^{\circledast}$ gibi) bugüne kadar bildirilmese de, diğer tüm kan ürünleri gibi viral hastalık bulaştırıcılığı açısından risk taşıdığ binan teknikle üretilen Rhucin ${ }^{\otimes} /$ Ruconest $^{\circledR}$ gibi ticari ürünlerin ise içinde bulundurduğu tavşan proteinlerine karşı geliştirebilecekleri Tip 1 (IgE-aracılı) hipersensitivite reaksiyonu sonucu anafilaksiye yol açabilecekleri bildirilmiştir. Ecallantide ise anafilaksiye yol açan hipersensitivite reaksiyonu oluşturabilen bir ticari üründür. Icatibant ise daha çok enjeksiyon yapılan yerde oluşan lokalize reaksiyonlar ile tanınır. .,18,20,33-37 $^{-10}$

\section{Sonuç}

Ülkemizde atak tedavisinde daha çok deneyim sahibi olduğumuz ve son 20 yıldır tüm Dünya'da kullanılan C1INH plazma konsantreleri verilebilir. Yine kısmen daha yeni geliştirilmiş ve yerli muadil müstahzarlar olan Icatin $^{\circledR}$ veya bradikant ${ }^{\circledR}$ (bradikinin reseptör $\beta 2$ antagonist) da atak tedavisinde diğer bir seçenek olarak kullanılabilir. Hiçbiri bulunamaz ise, taze donmuş plazma verilebilir (tablo 3). ${ }^{18}$ Kallikrein inhibitörü olarak bilinen Ecallantide (DX88, Kalbitor ${ }^{\circledR}$ ) bir ara ülkemize de getirilmiş olup, şu an Türkiye piyasasından çekilmiştir. ${ }^{49,58,59}$

\begin{tabular}{|c|c|c|c|c|c|}
\hline Ürün & Piyasa adı & Verilme Dozu & Kaynak & Uygulama yolu & Bilinen yan etkileri \\
\hline & \multicolumn{5}{|l|}{ Ülkemizde bulunan } \\
\hline pdC1-INH & Berinert / Cinryze ${ }^{\circ}$ & $20 \mathrm{IU} / \mathrm{kg} ; 1.000 \mathrm{U}$ & Plazma & Damar içi & $\begin{array}{c}\text { Tromboz, enfeksiyon } \\
\text { riski }\end{array}$ \\
\hline Icatibant & İcatin/Firazyr ${ }^{\circ}$ & $30 \mathrm{mg}$ & - & Cilt altı & $\begin{array}{l}\text { Enjeksiyon yeri reak- } \\
\text { siyonu }\end{array}$ \\
\hline \multirow[t]{2}{*}{ Taze donmuş plazma } & TDP & $10 \mathrm{ml} / \mathrm{kg} ; 400-800 \mathrm{ml}$ & Plazma & Damar içi & $\begin{array}{l}\text { Atağın seyir şiddetini } \\
\text { artırabilir }\end{array}$ \\
\hline & \multicolumn{5}{|c|}{ Yurt dışında bunlara ek olarak bulunan } \\
\hline rhC1-INH & Ruconest/Rhucin $^{\circ}$ & $50 \mathrm{IU} / \mathrm{kg}$ & Rekombinan & Damar içi & Anafilaksi \\
\hline Ecallantide & Kalbitor $^{\circ}$ & $30 \mathrm{mg}$ & - & Cilt alt1 & Anafilaksi \\
\hline $\begin{array}{l}\text { Solvent-deterjan } \\
\text { plazma }\end{array}$ & SDP & $10 \mathrm{ml} / \mathrm{kg} ; 400-800 \mathrm{ml}$ & Plazma & Damar içi & $\begin{array}{l}\text { Atağın seyir şiddetini } \\
\text { artırabilir }\end{array}$ \\
\hline
\end{tabular}




\section{Sakarya Tip Dergisi 2020;10(1):152-161}

ÖZDEMIR, Acilde Herediter Anjioödem

\section{Kaynaklar}

1. Özdemir Ö. Herediter anjioödemde tanı ve ayırıcı tanı. Turkiye Klinikleri J Allergy-Special Topics 2011;4(2):21-35.

2. Kelly $M$, Donnelly JP, McAnnally JR, Wang HE. National estimates of emergency department visits for angioedema and allergic reactions in the United States. Allergy Asthma Proc. 2013;34:150-4

3. Bertazzoni G, Spina MT, Scarpellini MG, Buccelletti F, De Simone $M$, Gregori $M$, et al. Drug-induced angioedema: experience of Italian emergency departments. Intern Emerg Med. 2014;9:455-62.

4. Felder S, Curtis RM, Ball I, Borici-Mazi R. Prognostic factors in outcome of angioedema in the emergency department. Allergy Asthma Proc. 2014; 35(5):362-70.

5. Bernstein JA, Cremonesi P, Hoffmann TK, Hollingsworth J. Angioedema in the emergency department: a practical guide to differential diagnosis and management. Int J Emerg Med. 2017; 10(1):15.

6. Bowen T, Cicardi M, Farkas H, Bork K, Longhurst HJ, Zuraw B, et al. 2010 International consensus algorithm for the diagnosis, therapy and management of hereditary angioedema. Allergy Asthma Clin Immunol. 2010; 6(1):24.

7. Özdemir Ö, Elmas B. Türkiye’de bir şehirde indeks herediter anjioödem hastalarının uzak ve yakın test edilmemiş akrabalarında herediter anjioödem prevalans ve klinik belirtileri. JAREM 2017; 7:51-7.

8. Zuraw BL. Hereditary angioedema with normal $\mathrm{Cl}$ inhibitor: Four types and counting. $J$ Allergy Clin Immunol. 2018; 141(3):884-5.

9. Lumry WR. Overview of epidemiology, pathophysiology, and disease progression in hereditary angioedema. Am J Manag Care. 2013; 19 (7 Suppl):s103-10.

10. Gülbahar O, Gelincik A, Sin A, Güleç M, Yllmaz M, Gökmen NM, et al. Herediter anjioödem. Asthma Allergy Immunol 2010; 8: 125-38.

11. Zuraw BL, Christiansen SC. HAE pathophysiology and underlying mechanisms. Clin Rev Allergy Immunol. 2016;51(2):216-29.

12. Özdemir Ö. Innovations in Hereditary Angioedema Pathophysiology. South. Clin. Ist. Euras. 2019;30(4):355-361

13. Ozdemir O. New developments in type of hereditary angioedema with normal CI-inhibitor level. MOJ Immunol. 2019;7(1):1-2.

14. Dewald G, Bork K. Missense mutations in the coagulation factor XII (Hageman factor) gene in hereditary angioedema with normal C1 inhibitor. Biochem Biophys Res Commun 2006; 343:1286-9.

15. Bork K, Wulff K, Steinmüller-Magin L, Braenne I, Staubach-Renz P, Witzke G, et al. Hereditary angioedema with a mutation in the plasminogen gene. Allergy 2018; 73(2):44250.

16. Bafunno V, Firinu D, D’Apolito M, Cordisco G, Loffredo S, Leccese A, et al. Mutation of the angiopoietin-1 gene (ANGPTI) associates with a new type of hereditary angioedema. J Allergy Clin Immunol. 2018; 141(3): 1009-17.

17. Cicardi M, Aberer W, Banerji A, Bas M, Bernstein JA, Bork K, et al. Classification, diagnosis, and approach to treatment for angioedema: consensus report from the Hereditary Angioedema International Working Group. Allergy 2014; 69(5):60216.

18. Bahceci SE, Genel F, Gulez N, Nacaroglu HT. Coexistence of hereditary angioedema in a case of familial Mediterranean fever with partial response to colchicine. Cent Eur I Immunol. 2015; 40(1): 115-6

19. Maurer M, Magerl M, Ansotegui I, Aygören-Pürsün E, Betschel S, Bork K, et al. The international WAO/EAACI guideline for the management of hereditary angioedema-The 2017 revision and update. Allergy 2018; 73(8):1575-96.

20. Betschel S, Badiou J, Binkley K, Hébert J, Kanani A, Keith P, et al. Canadian hereditary angioedema guideline. Allergy Asthma Clin Immunol. 2014;10(1):50.

21. Özdemir Ö. Mast Hücre- Aracıl (Histaminerjik) Anjioödeme Yaklașım: Klinik Spektrum ve Tani. Sakarya Tip Dergisi. 2019; 9(3): 378-369.

22. Busse PJ, Smith T. Histaminergic Angioedema. Immunol Allergy Clin North Am. 2017; 37(3):467-81.

23. Craig TJ, Bernstein JA, Farkas H, Bouillet L, Boccon-Gibod I. Diagnosis and treatment of bradykinin-mediated angioedema: outcomes from an angioedema expert consensus meeting. Int Arch Allergy Immunol. 2014;165(2):11927.

24. Özdemir Ö. Tekrarlayan anjiyoödem atakları ile başvuran hastaya akılcı yaklașım. Klinik Tip Pediatri Dergisi 2019; 11 (2): 64-73

25. Betschel S, Avilla E, Kanani A, Kastner M, Keith P, Binkley K, et al. Development of the Hereditary Angioedema Rapid Triage Tool (HAE-RT). J Allergy Clin Immunol Pract. 2019 Jun 22. pii: S2213-2198(19)30562-8. [Epub ahead of print]
26. Butterfield JH, Leiferman KM, Gleich GJ. Nodules, eosinophilia, rheumatism, dermatitis and swelling (NERDS): a novel eosinophilic disorder. Clin Exp Allergy. 1993; 23(7):571-80.

27. Farkas H, Martinez-Saguer I, Bork K, Bowen T, Craig T, Frank M, et al. International consensus on the diagnosis and management of pediatric patients with hereditary angioedema with C1 inhibitor deficiency. Allergy. 2017; 72(2): 300-13.

28. Frank MM, Zuraw B, Banerji A, Bernstein JA, Craig T, Busse P, et al. Management of children with hereditary angioedema due to $C 1$ inhibitor deficiency. Pediatrics 2016; 138(5). pii: e20160575.

29. Nasr IH, Manson AL, Al Wahshi HA, Longhurst HJ. Optimizing hereditary angioedema management through tailored treatment approaches. Expert Rev Clin Immunol. 2016; 12(1): 19-31.

30. Sabharwal G, Craig T. Pediatric hereditary angioedema: an update. F1000Res. 2017; 6.

31. Pattanaik D, Lieberman JA. Pediatric angioedema. Curr Allergy Asthma Rep. 2017; 17(9): 60 .

32. MacGinnitie AJ. Pediatric hereditary angioedema. Pediatr Allergy Immunol 2014: 25: 420-7.

33. Lang DM, Aberer W, Bernstein JA, Chng HH, Grumach AS, Hide M, et al. International consensus on hereditary and acquired angioedema. Ann Allergy Asthma Immunol. 2012; 109 (6): 395-402.

34. Zuraw BL, Bernstein JA, Lang DM, Craig T, Dreyfus D, Hsieh F, et al. A focused parameter update: hereditary angioedema, acquired Clinhibitor deficiency, and angiotensin-converting enzyme inhibitor-associated angioedema. J Allergy Clin Immunol. 2013; 131(6): 14913.

35. Hakl R, Kuklinek P, Krčmová I, Králičková P, Freiberger T, Janků P, et al. Treatment of Hereditary Angioedema Attacks with Icatibant and Recombinant C1 Inhibitor During Pregnancy. J Clin Immunol. 2018;38(7):810-5.

36. Jose J, Zacharias J, Craig T. Review of select practice parameters, evidence-based treatment algorithms, and international guidelines for hereditary angioedema. Clin Rev Allergy Immunol. 2016; 51(2):193-206

37. Longhurst H. Optimum Use of Acute Treatments for Hereditary Angioedema: Evidence-Based Expert Consensus. Front Med (Lausanne). 2018; 4:245

38. Tse KY, Zuraw BL, Chen Q, Christiansen SC. Anabolic androgen use in the management of hereditary angioedema: Not so cheap after all. Ann Allergy Asthma Immunol. 2017; 118 (4):456-60.e1.

39. Bernstein JA, Relan A, Harper JR, Riedl M. Sustained response of recombinant human C1 esterase inhibitor for acute treatment of hereditary angioedema attacks. Ann Allergy Asthma Immunol 2017; 118(4):452-5.

40. Baker JW, Reshef A, Moldovan D, Harper JR, Relan A, Riedl MA. Recombinant Human C1-esterase inhibitor to treat acute hereditary angioedema attacks in adolescents. J Allergy Clin Immunol Pract. 2017; 5(4):1091-7.

41. Riedl MA, Li HH, Cicardi M, Harper JR, Relan A. Recombinant human C1 esterase inhibitor for acute hereditaryangioedema attacks with upper airway involvement. Allergy Asthma Proc. 2017; 38(6):462-6.

42. Chen M, Riedl MA. Emerging therapies in hereditary angioedema. Immunol Allergy Clin North Am. 2017; 37(3):585-95.

43. Lumry WR. Current and emerging therapies to prevent hereditary angioedema attacks. Am J Manag Care. 2018; 24(14 Suppl):S299-S307.

44. Perego F, Wu MA, Valerieva A, Caccia S, Suffritti C, Zanichelli A, et al. Current and emerging biologics for the treatment of hereditary angioedema. Expert Opin Biol Ther. 2019. $1-10$.

45. Farkas H. Hereditary angioedema: examining the landscape of therapies and preclinical therapeutic targets. Expert Opin Ther Targets. 2019; 23(6):457-9.

46. Baysan A, Güleç M. Herediter anjioödemde atakların önlenmesi. Turkiye Klinikleri J Allergy-Special Topics 2011;4(2): 36-43.

47. Akkor Gelincik A. Herediter anjioödemde akut ataklarm tedavisi. Turkiye Klinikleri J Allergy-Special Topics 2011;4(2):44-50.

48. Duffey H, Firszt R. Management of acute attacks of hereditary angioedema: role of ecallantide. J Blood Med. 2015; 6:115-23.

49. Katelaris CH. Acute management of hereditary angioedema attacks. Immunol Allergy Clin North Am. 2017; 37(3):541-56.

50. Otani IM, Christiansen SC, Busse P, Camargo CA Jr, Zuraw BL, Riedl MA, et al. Emergency department management of hereditary angioedema attacks: Patient perspectives. J Allergy Clin Immunol Pract. 2017; 5(1):128-34.e4.

51. Zanichelli A, Azin GM, Cristina F, Vacchini R, Caballero T. Safety, effectiveness, and impact on quality of life of self-administration with plasma-derived nanofiltered $\mathrm{Cl}$ inhibitor 
Sakarya Tip Dergisi 2020;10(1):152-161

ÖZDEMIR, Acil'de Herediter Anjioödem

(Berinert $\left.{ }^{\circ}\right)$ in patients with hereditary angioedema: the SABHA study. Orphanet J Rare Dis 2018; 13(1):51.

52. Li H, Riedl M, Kashkin J. Update on the use of C1-esterase inhibitor replacement therapy in the acute and prophylactic treatment of hereditary angioedema. Clin Rev Allergy Immunol 2019; 56(2):207-18.

53. Caballero T, Aberer W, Longhurst HJ, Maurer M, Zanichelli A, Perrin A, et al. The Icatibant Outcome Survey: experience of hereditary angioedema management from six European countries. J Eur Acad Dermatol Venereol. 2017; 31(7):1214-22.

54. Longhurst HJ, Zanichelli A, Caballero T, Bouillet L, Aberer W, Maurer M, et al. Comparing acquired angioedema with hereditary angioedema (types I/II): findings from the Icatibant Outcome Survey. Clin Exp Immunol. 2017; 188(1):148-53.

55. Lumry WR, Farkas H, Moldovan D, Toubi E, Baptista J, Craig T, et al. Icatibant for multiple hereditary angioedema attacks across the controlled and open-label extension phases of FAST-3. Int Arch Allergy Immunol. 2015;168(1):44-55.
56. Farkas H, Reshef A, Aberer W, Caballero T, McCarthy L, Hao J, et al. Treatment effect and safety of Icatibant in pediatric patients with hereditary angioedema. J Allergy Clin Immunol Pract. 2017; 5(6):1671-8.e2.

57. Longhurst HJ, Aberer W, Bouillet L, Caballero T, Maurer M, Fabien V, et al. The Icatibant Outcome Survey: treatment of laryngeal angioedema attacks. Eur J Emerg Med 2016; 23(3):224-7.

58. Craig TJ, Li HH, Riedl M, Bernstein JA, Lumry WR, MacGinnitie AJ, et al. Characterization of anaphylaxis after ecallantide treatment of hereditary angioedema attacks. J Allergy Clin Immunol Pract. 2015;3(2):206-12.e4.

59. Bowen T, Cicardi M, Farkas H, Bork K, Kreuz W, Zingale L, et al. Canadian 2003 international consensus algorithm for the diagnosis, therapy, and management of hereditary angioedema. J Allergy Clin Immunol. 2004; 114(3):629-37. 